\title{
Affinities of the Philippine Negritos as Viewed from Dental Characters: A Preliminary Report
}

\author{
Tsunehiko HANIHARA \\ Department of Anatomy, Jichi Medical School
}

\begin{abstract}
Dental characteristics of Aeta, one of the Negrito tribes in westcentral Luzon, the Philippines, were compared with those of Japanese, Ainu, PimaIndians, Australian Aborigines, Filipinos, American Caucasoids and American Blacks. The overall tooth size of Negritos is smallest among the populations compared and closest to Ainu. As regards the shape factor of the dental measurements, they are closely related to Mongoloid populations as revealed by $\mathrm{Q}$-mode correlation coefficients. These findings are almost parallel to the results obtained by principal component analysis. On the other hand, Bsquare distances based on seven non-metric crown characters show close affinity between Negritos and Ainu. The frequency distribution of the crown characters in both populations well corresponds to the "Sundadont" pattern defined by TURNER (1987).

The results obtained from the present study, together with TURNER's $(1978,1979,1987,1989)$ dental anthropological model of the late Pleistocene population history in southeast Asia, support the hypothesis proposed by Омото (1984, 1986) who suggested that Negritos might have shared an ancestral stock with Semang of Malaysia and evolved in the upper Pleistocene times under the environment of tropical rain-forest in Sundaland.
\end{abstract}

Keywords Negritos, Dental characters, Sundaland, Proto-Mongoloid, Southeast Asia

\section{Introduction}

The Negritos, inhabiting the remote areas of the Philippines, southeast Asia and Andaman Islands, have such phenotypic characteristics as short stature, dark skin color and frizzly hair.

The origin and microevolution of Negritos have been the subject of controversy in the field of physical anthropology (SCHEBESTA, 1957 ; Омото, et al., 1978; Омото, 1984). Concerning Negritos of the Little Andaman Island, KumAR and MukHERJEe (1983) showed marked divergence of this population from the other Negrids, especially from those in Africa, and indicated a

Article No. 8908 Received April 10, 1989 
possible migration from Malayan Archipelago based on the blood genetic studies. The same suggestion was also advanced by Cipriani (1966), Reynolds (1976) and CADELINA (1984) who carried out ethnographical studies on the Philippine Negritos.

During 1976-1982 period, Омото organized a research project under the title "Population Genetic Survey of the Negritos" and a number of papers on human genetic studies were published (Омото, et al., 1978, 1981 ; Омото, 1979, 1980, 1981, 1984 ; MATsUMOTO, et al., 1979; HoRAI, et al., 1981 ; HARIHARA, et al., 1988). In the first year of this survey, plaster casts of the permanent dentition of Aeta (Negrito in sensu stricto living in Luzon) were made by SAKAI who was a dentist and one of the project members.

These excellent studies revealed that Negritos were genetically more closely related to Asian-Pacific population groups than to African groups (Омото, 1981, 1984 ; HARIHARA, et al., 1988). It was also elucidated that there were genetically two distinct groups in the so-called Philippine Negritos, one having been Aeta including some other groups of Luzon and another Mamanwa of Mindanao. The former group is said to show close affinity to southeast Asian populations and the latter to be derived from the ancestral Proto-Malay of Late Pleistocene Sundaland (Омото, 1984). Омото (1984, 1986, 1987) goes further to suggest a close relationship between Aeta and Proto-Mongoloid populations.

In regard to morphology, on the other hand, no reliable studies of Negritos have so far been reported. Although importance of the anatomical characteristics of this population has been emphasized by some authorities (e. g. HowelLs, 1970, 1976, 1977), few papers based on concrete data have been published.

Dental morphology provides one of the most important grounds for studies on evolution and affinities of different populations. Interpopulation differences in tooth structure enable us to reconstruct the history and evolution of modern human populations (TURNER, 1989). In this concern, the present study was focused to obtain additional informations for discussing affinities of Negritos on the basis of metric and nonmetric dental traits.

\section{Materials and Methods}

The Negrito samples in the present study consist of 25 individuals (21 males and 4 females) from Aeta of west-central Luzon, the Philippines. The control populations for comparison are Japanese, Ainu, and Filipinos living in the Marcos village. All the materials are plaster casts of the permanent dentition housed at Department of Anthropology and Prehistory, the University Museum, the University of Tokyo. The data of Pima-Indians, Australian Aborigines, American Caucasoids and American Blacks reported by K. HANIHARA (1976) were used for comparison (Table 1). In the following text, Pima-Indians, American Caucasoids and American Blacks are simply referred to as Pimas, Caucasoids and Blacks, respectively.

As regards metric traits, mesiodistal crown diameters of all the teeth except for the upper and lower third molars were measured. The usefulness of this measure in comparative studies was discussed in the previous paper (T. HANIHARA, 1989b). The nonmetric crown characters recorded are shovel shape in the upper central incisors; CARABELli's cusp in the upper first molars ; 6th cusp, 7th cusp, deflecting wrinkle and 
Table 1. Numbers of samples used in metric analyses (male)

\begin{tabular}{lll}
\hline \multicolumn{1}{c}{ Population } & N & \multicolumn{1}{c}{ Author } \\
\hline Negrito & 21 & Present study \\
Japanese & 50 & Present study \\
Ainu & 20 & Present study \\
Filipino & 14 & Present study \\
Pima-Indian & 60 & HANiHARA (1976) \\
Australian Aborigine & 95 & HANiHARA (1976) \\
American White & 40 & HANIHARA (1976) \\
American Black & 47 & HANIHARA (1976) \\
\hline
\end{tabular}

protostylid in the lower first molars; and +4 pattern in the lower second molars. Both metric and nonmetric data were obtained from the right side teeth. When a particular tooth is missing or badly damaged on the right side, the corresponding left side tooth was measured and/or observed.

In analyzing the metric traits, the measurements for males were used. In the nonmetric crown characters, male and female samples were combined because between-sex differences in frequencies were insignificant in most of the populations observed.

Statistical methods applied for the dental measurements were PENRosE's size distance, principal co-ordinate analysis, Q-mode correlation coefficients, cluster analysis and principal component analysis. Those for frequencies of nonmetric crown traits were BALAKRISHNAN and SANGHVI's B-square distances (1968), cluster analysis and principal co-ordinate analysis. The B-squares are computed in mathematically more sophisticated way than any other distances. This method has advantages in using dispersion matrix which warrants 'decorrelation' of the elements of frequency vectors and in providing the contribution rates of each trait to the distance coefficient.

All the above calculations were performed with NEC personal computer model $9801-\mathrm{Vm} 2$ and statistical analysis programs coded by K. HANiHARA.

\section{Analysis of the Mesiodistal Crown Diameters}

Fig. 1 gives one-dimensional expression of the group constellation resulted from principal co-ordinate analysis of PENROSE's size distances. The populations are arranged, from left to right, in the ascending order of overall tooth size. It is easily recognized that Negritos are smallest in overall tooth size, and Ainu comes next. Filipinos show intermediate size among the populations compared. The original tooth size of Filipinos, however, may have changed through hybridization with Caucasians, especially with Spanish. Detailed descriptions on the other populations were already given by K. HANiHARA $(1976,1979)$ and T. HANIHARA (1989a, 1989b).

In comparing dental measurements, shape

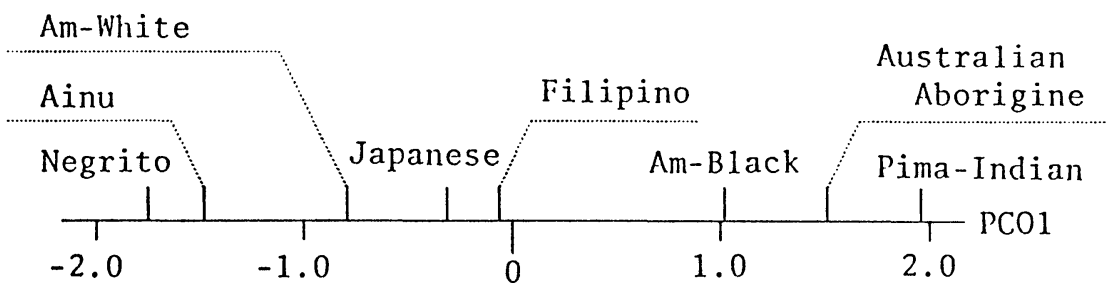

Fig. 1. One dimensional expression of the eight populations based on the Penrose's size distances. 


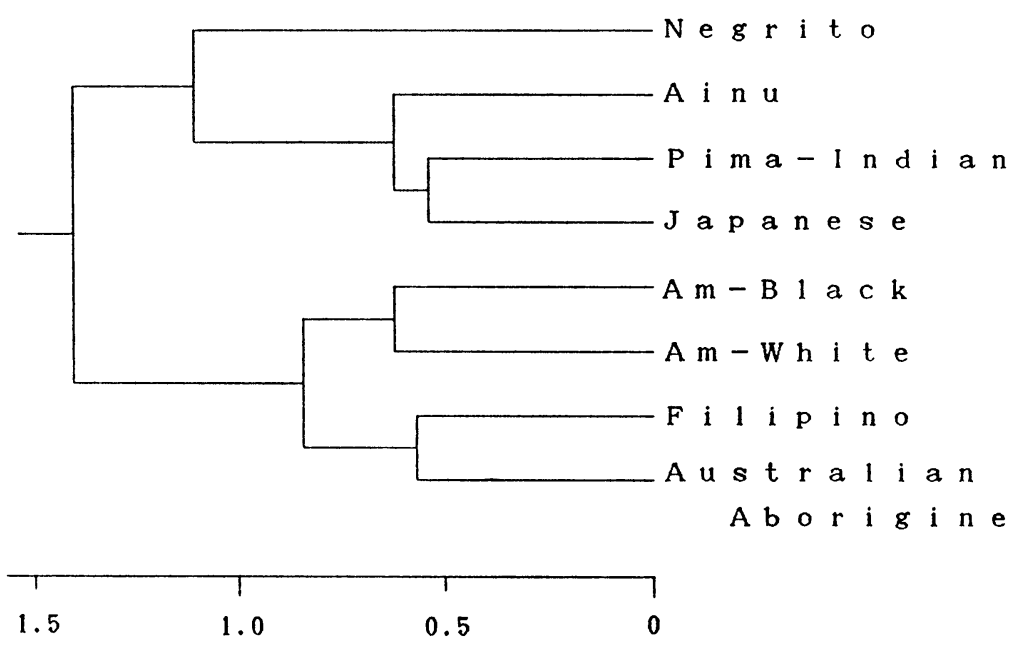

Fig. 2. Dendrogram drawn from the distance matrix transformed from Q-mode correlation coefficients among the eight populations.

factor represents affinities among different populations much better than size factor. Fig. 2 demonstrates clustering of the eight populations. The dendrogram was drawn by the group average method based on the distance matrix transformed from Q-mode correlation matrix which represent similarity between populations. It is quite likely that Negritos have closer affinities to the Mongoloid populations than to Caucasians, Blacks, Australian Aborigines and Filipinos.

For the purpose of obtaining more detailed and concrete informations, the principal component analysis was performed. The correlation matrix used in the analysis was calculated from a pooled covariance matrix obtained from mesiodistal crown diameters of all the populations. Table 2 gives eigenvectors for the first three principal components. The first two components have eigenvalues greater than 1.0, but their cumulative proportion of total variance is only 0.66 . If the third component is included, the cumulative proportion increases to 0.73 . The first three principal components are, therefore, worth considering in morphological analysis.

On the basis of eigenvectors, each principal component can be explained as follows: the 1st principal component represents overall tooth size; the 2nd component is a shape factor which contrasts the anterior tooth size (incisors and canines) to the posterior tooth size (premolars and molars); and the 3rd one is another shape factor contrasting the size of canine and premolar to that of other teeth (incisors and molars).

Table 3 shows the mean principal component scores of different populations and Fig. 3 was drawn on the basis of the first principal component scores. The populations are scattered in the order of tooth size, Negritos being the smallest and Pimas the largest. The result obtained is in full agreement with that from the PENROSE's size distance.

On the other hand, populations in Fig. 4 are plotted according to the second and 
Table 2. Eigenvalues and eigenvectors of the correlation matrix used in the principal component analysis

\begin{tabular}{lrrr}
\hline \multicolumn{1}{c}{ Tooth } & 1st PC & 2nd PC & 3rd PC \\
\hline U I 1 & 0.26987 & -0.17650 & 0.27266 \\
U I 2 & 0.22986 & -0.39165 & 0.16093 \\
U C & 0.26827 & -0.29267 & -0.24888 \\
U P 3 & 0.29692 & 0.07823 & -0.36138 \\
U P 4 & 0.28228 & 0.10939 & -0.33328 \\
U M1 & 0.27371 & 0.25357 & 0.23231 \\
U M2 & 0.24058 & 0.36245 & 0.38507 \\
L I 1 & 0.25656 & -0.25773 & 0.25470 \\
L I 2 & 0.28365 & -0.34514 & 0.11779 \\
L C & 0.28256 & -0.30041 & -0.16819 \\
L P 3 & 0.25580 & 0.19969 & -0.36653 \\
L P 4 & 0.22720 & 0.29828 & -0.23258 \\
L M1 & 0.25116 & 0.19229 & 0.13009 \\
L M2 & 0.26505 & 0.27238 & 0.28550 \\
\hline Eigenvalue & 7.84040 & 1.40377 & 0.98057 \\
Proportion & 0.56003 & 0.10027 & 0.07004 \\
Cumulative Prop. & 0.56003 & 0.66030 & 0.73034 \\
\hline
\end{tabular}

Table 3. Mean principal component scores in each population

\begin{tabular}{lrrr}
\multirow{2}{*}{ Populaticn } & \multicolumn{3}{c}{ Principal component No. } \\
\cline { 2 - 4 } & \multicolumn{1}{c}{1} & \multicolumn{1}{c}{2} & \multicolumn{1}{c}{3} \\
\hline Negrito & -3.054 & 0.234 & -0.638 \\
Japanese & -1.070 & -0.283 & -0.475 \\
Ainu & -2.860 & -0.827 & -0.009 \\
Filipino & -0.291 & 1.137 & 0.167 \\
Pima-Indian & 2.128 & -0.665 & -0.270 \\
Australian & 1.171 & 0.298 & 0.833 \\
$\quad$ Aborigine & -2.192 & 0.910 & 0.337 \\
Am-White & 0.426 & 1.110 & -0.219 \\
Am-Black & & &
\end{tabular}

third principal component scores which represent shape factors of the dental measurements. The eight populations are roughly divided into three clusters: 1) cluster of Caucasoids, Blacks and Filipinos;2) cluster of Australian Aborigines; and 3) cluster of Negritos, Japanese, Pimas and Ainu.
The second principal component scores contrasting the anterior and posterior tooth sizes are larger in Caucasoids, Blacks and Filipinos. The scores obtained, therefore, show that these populations are characterized by relatively large posterior teeth and small anterior teeth. The Mongoloid populations such as Japanese, Pimas and Ainu, on the other hand, show the reverse type. These results are fully consistent with those obtained by K. HANIHARA (1974) who proposed the term 'molar type' for the former group and 'incisor type' for the latter. Negritos and Australian Aborigines represent intermediate scores between the two types.

In more detail, Negritos and Australian Aborigines have close affinity to each other in the shape factor as represented by the second principal component, while they are different in the third principal component 


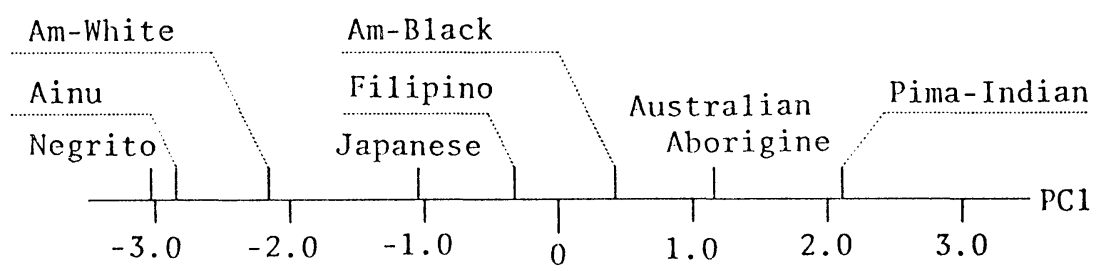

Fig. 3. One dimensional expression of the scores of the first principal component.

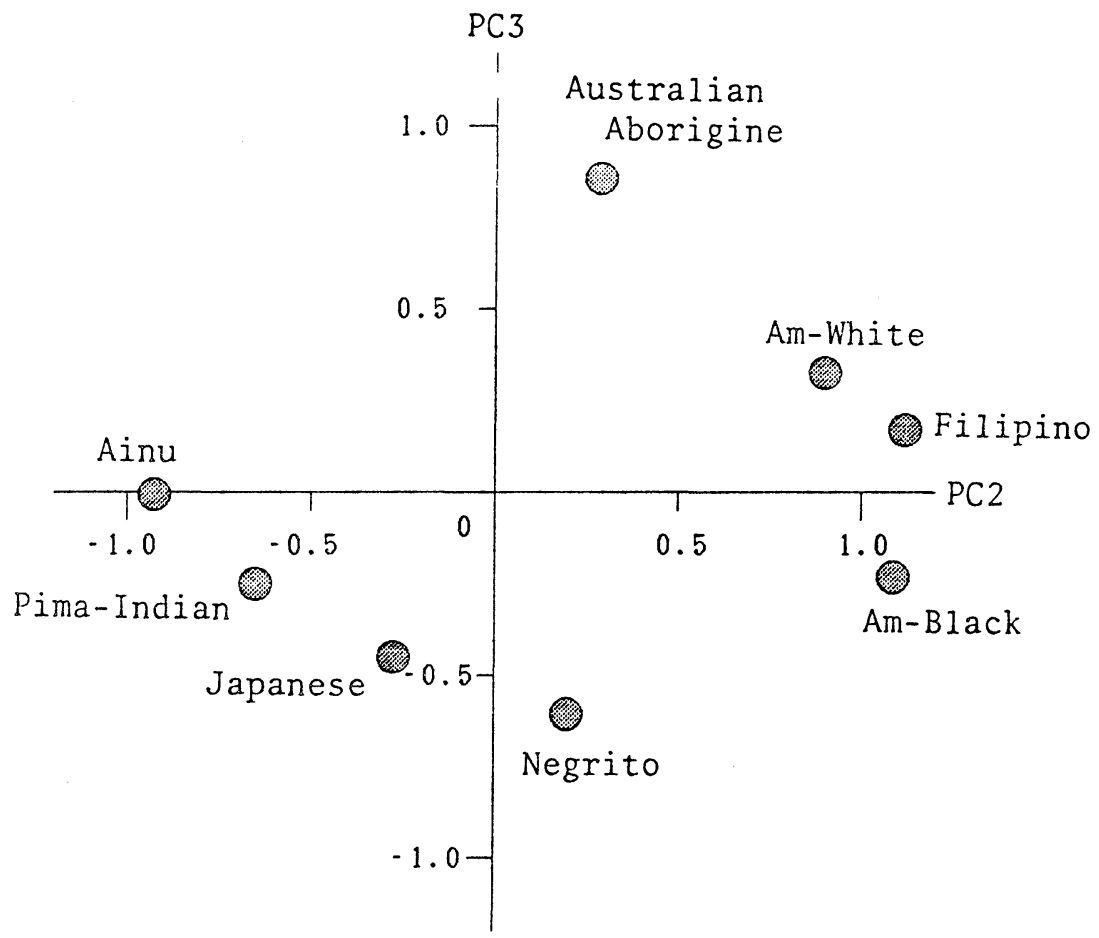

Fig. 4. Diagram drawn from the second and third principal component scores.

scores showing that the canine-premolar group is relatively large in Negritos but the molar group is relatively large in Australian Aborigines.

\section{Analysis of Nonmetric Crown Characters}

Since the sample size for Filipino is so small (14 males and 3 females) that this population is excluded from the following analysis. The nonmetric crown traits recorded and their frequencies were listed in Table 4. For Australian Aborigines, Pimas, Caucasoids and Blacks, the data given by $\mathrm{K}$. HANIHARA (1976) were used for comparison. Table 5 gives a matrix of BALAKRISHNAN and SANGHVI's B-square distances calculated from the frequencies of crown characters.

Fig. 5 illustrates the contribution rates of each character to the distances between 
Table 4. Frequency distributions of tooth crown traits (in \%)

\begin{tabular}{llcccccc}
\hline Population & $\begin{array}{c}\text { Shovel } \\
\text { (UI1) }\end{array}$ & $\begin{array}{c}\text { CARA- } \\
\text { BELL1' } \\
\text { (UM1) }\end{array}$ & $\begin{array}{c}\text { 6th Cusp } \\
\text { (L M1) }\end{array}$ & $\begin{array}{c}\text { 7th Cusp } \\
\text { (LM1) }\end{array}$ & $\begin{array}{c}\text { Defl. } \\
\text { Wrinkle } \\
\text { (LM1) }\end{array}$ & $\begin{array}{c}\text { Protostylid } \\
\text { (LM1) }\end{array}$ & $\begin{array}{c}+4 \\
\text { pattern } \\
\text { (LM2) }\end{array}$ \\
\hline Negrito & $66.7(21)$ & $25.0(20)$ & $17.7(17)$ & $11.8(17)$ & $17.7(17)$ & $5.9(17)$ & $58.8(17)$ \\
Japanese & $95.1(492)$ & $6.5(444)$ & $42.6(342)$ & $4.3(342)$ & $30.7(342)$ & $6.4(485)$ & $26.0(96)$ \\
Ainu & $72.9(70)$ & $10.2(98)$ & $23.8(84)$ & $2.4(84)$ & $28.6(84)$ & $12.2(82)$ & $60.3(63)$ \\
Pima-Ind. & $99.1(222)$ & $6.9(216)$ & $26.6(207)$ & $8.2(208)$ & $39.5(205)$ & $19.4(217)$ & $28.0(89)$ \\
Aust. Abor. & $89.8(166)$ & $1.7(159)$ & $52.5(162)$ & $6.5(155)$ & $41.1(163)$ & $6.1(165)$ & $52.0(12)$ \\
Am-White & $27.7(83)$ & $35.0(59)$ & $5.2(58)$ & $5.1(59)$ & $3.6(56)$ & $0.0(81)$ & $84.1(57)$ \\
Am-Black & $37.2(78)$ & $16.39(80)$ & $6.5(77)$ & $43.6(78)$ & $16.3(80)$ & $0.0(78)$ & $49.0(218)$ \\
\hline
\end{tabular}

Table 5. BALAKRISHNAN's square distance between populations based on non-metric crown characters

\begin{tabular}{lccccccc}
\hline & Negrito & JPN & Ainu & P-Ind. & Aust. Abor. & Am-W & Am-B \\
\hline Negrito & - & & & & & & \\
Japanese & 1.250 & - & & & & & \\
Ainu & 0.482 & 0.834 & - & & & & \\
Pima-Ind. & 2.136 & 0.722 & 1.244 & - & & & \\
Aust. Abor. & 1.458 & 0.483 & 0.860 & 0.981 & - & & \\
Am-White & 2.029 & 5.614 & 3.385 & 7.998 & 6.043 & - & \\
Am-Black & 2.421 & 4.929 & 4.051 & 6.291 & 5.738 & 3.319 & - \\
\hline
\end{tabular}

Negritos and the other populations compared. It is quite evident that the frequency of shovel shape plays an important role for distinguishing the populations, and the lower frequency of this trait in Negritos attracts our special attention in this regard.

Among other crown characters, frequencies of the 6th cusp and deflecting wrinkle in the mandibular first molar are lower in Negritos than in Japanese, Pimas, and Australian Aborigines but higher than in Caucasoids and Blacks with a few exceptions. On the other hand, those of the +4 pattern in the mandibular second molar is higher in Negritos than in the former group but lower than in the latter group. In general, the frequencies of dental traits in Negritos agree with the characteristics of 'Sundadonty' defined by TURNER (1987, 1989), and the closest morphological affinity is found between Negritos and Ainu.

Fig. 6 illustrates a dendrogram based on the distance matrix given in Table 5 and drawn by the group average method. Negritos and Ainu are again closely related to each other, and they show closer affinity to Japanese, Pimas and Australian Aborigines than to Caucasoids and Blacks. Fig. 7 shows a two-dimensional scattergram drawn by principal co-ordinate analysis of the B-square distances. Perhaps the most notable finding in this figure is that a cluster of Negritos and Ainu is more closely related to Australian Aborigines than to Japanese and Pimas. As regards the affinity between Japanese and Australian Aborigines in the nonmetric crown characters, the detailed discussion has been already made 


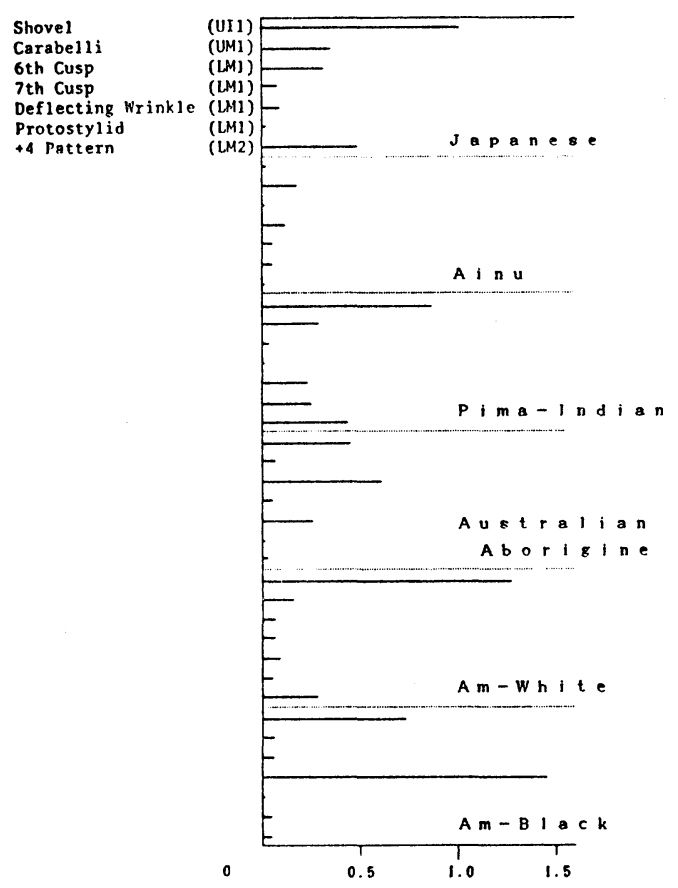

Fig. 5. Contribution rates of total variance for B-squares. by K. Hanihara (1976).

\section{Discussion}

Among several ethnological and anthropological investigations on the Philippine Negritos, the studies undertaken by Омото and his colleagues $(1978,1984,1986,1987)$ have been focused to their origins and affinities which were the subject of controversy.

As regards the genetic origin and the microevolution of Negritos, Омото (1984) proposed the hypothesis that large part of Negritos including Aeta might be more closely related to the southeast Asian populations than to Australian Aborigines. On the other hand, Birdsell $(1949,1977)$, CoON (1962), JACOB (1967) and Howelds (1970, 1976, 1977) stressed that there existed basically Austro-Melanesian characters in Negritos (Old Melanesians in Howells' terminology). They provided, however, no satisfactory explanations to cover all the available evidence.

The present study revealed that the overall tooth size of Negritos was smaller than that of Ainu who had been reported to carry the smallest teeth in Asia (BRACE and NAGAI,
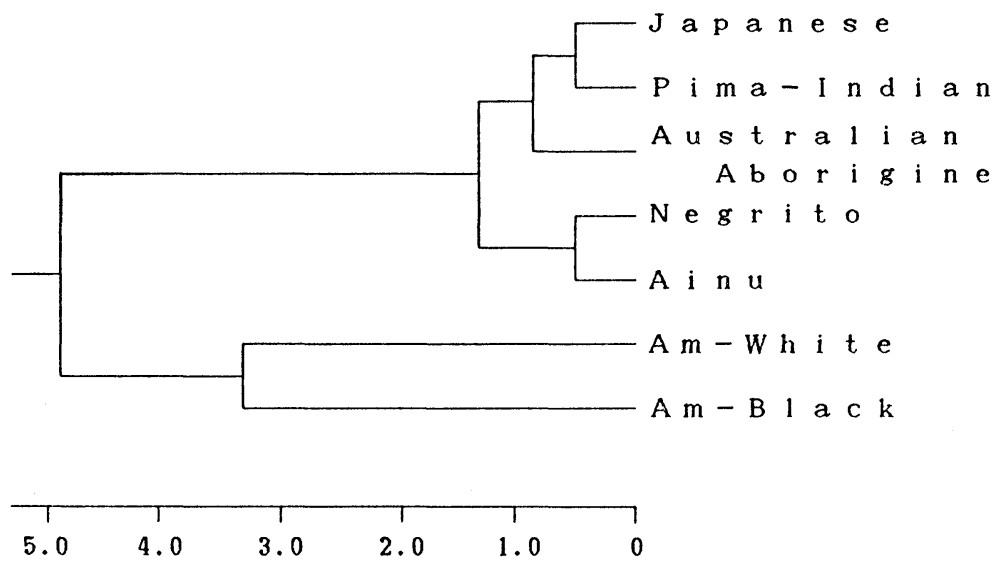

Fig. 6. Dendrogram drawn from the B-square distance matrix. 


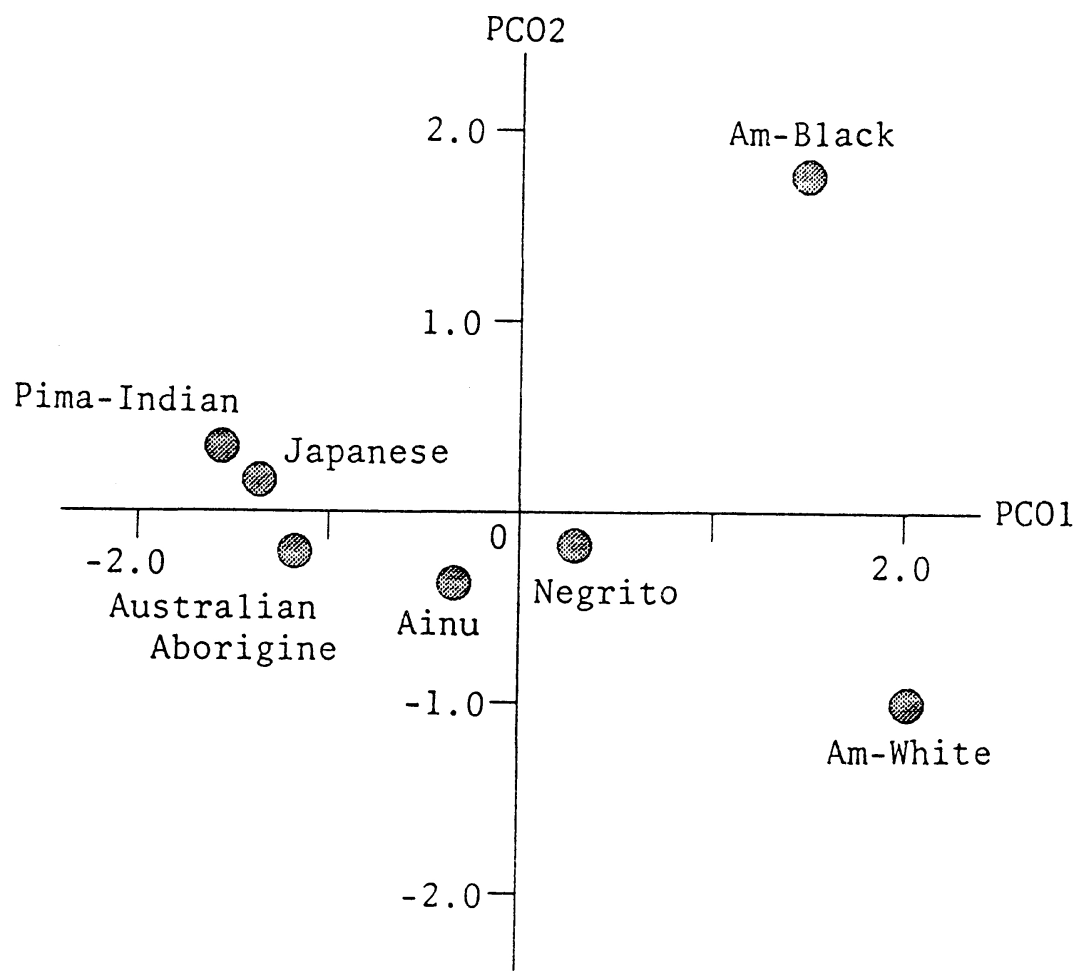

Fig. 7. Two dimensional expression by principal co-ordinate analysis based on the B-square distance matrix.

1982). Viewed from the shape factor of dental measurements, Negritos are likely included in the Mongoloid population cluster and, at the same time, they share some similar characteristics with Australian Aborigines as shown by the principal component analysis.

In the nonmetric crown characters, it is of quite interest to note that Negritos are closest to Ainu than to any other populations compared and, as shown in Fig. 7, both populations are located more closely to Australian Aborigines than to Japanese and Pimas. However, the result does not necessarily mean a close affinity between the Ainu-Negrito group and Australian Aborigines as suggested by YAMAGUCHI (1967),
Omoto (1972), K. Hanihara (1976) and others since several problems concerning the relationsphip between Negritos and Australian Aborigines are still remained unanswered.

As shown in this study, Negritos are largely similar to Mongoloid populations in dental morphology, less to Australian Aborigines and quite different from Caucasoids and Blacks. BiRdSELL (1949, 1977) regarded Negritos as direct ancestors of Australian Aborigines. According to Омото's hypothesis (1984, 1986, 1987), Negritos are related to modern Australian Aborigines only through their common ancestral type "Proto-Australoid". The dental evidence presented here supports this hypothesis and clearly indicates 
that Negritos derived from the ancestral stock of Asian populations, not from Africans.

Aeta is said to be the true Negrito or Negrito in sensu stricto (Омото, 1981, 1984). Омото (1984) suggested that this population might have shared an ancestral stock with the Semang of Malaysia and evolved in the Upper Pleistocene times, probably during 20,000 to 30,000 years B.P., in the tropical rain-forest of Sundaland and they are called Proto-Malays (GLinKA, 1981; Омото, 1984, 1986). Омото (1984) goes further to say that the direct descendants of the ProtoMalays may be Mamanwa of Mindanao. On the other hand, Aeta of Luzon might have been influenced by the Proto-Mongoloid agriculturists intruding from the Asian mainland, culturally as well as physically, some 10,000-20,000 years B.P. (Howells, 1976; KenNEDY, 1979; Омото, 1984). It is quite possible, from this viewpoint, that there might have been genetic interrelationship between Negritos (Aeta) and ProtoMongoloid population in the past (Омото, 1986, 1987).

Based on the frequencies of nonmetric dental characters, another hypothesis has been proposed: in the late Pleistocene nowflooded Sundaland could have been occupied by a population ancestral to the ProtoMongoloid and those who extended to most northern Pacific might become the Neolithic Jomon population and modern Ainu (TURNER and SWINDLER, 1978; TURNER, 1976, 1979, 1987, 1989). TURNER $(1978,1979,1987,1989)$ referred to their tooth pattern as 'Sundadont'. Applying TURNER's terminology, the pattern of nonmetric crown traits in Negritos is evidently classified into the "Sundadont".

Taking the dental evidence presented in this study as well as hypothesis proposed by OMOTO and that by TURNER into account, it is highly probable that Negritos (Aeta) are closely related to the southeast Asian Proto-Mongoloid population and they still maintain some ancestral dental characteristics. The issue in the future is to obtain additional dental data from the other Pacific populations which allow more detailed discussions on the origins and divergence of Mongoloids including modern Japanese.

\section{Acknowledgments}

First of all, I wish to express my sincere gratitudes to Professor K. OMOTo of Department of Anthropology, the University of Tokyo, for his permission to study the Negrito's dental materials which were collected during his field survey in the Philippines. I am grateful to Dr. K. SAKAI who made the dental casts of Negritos used in this study. I am also deeply indebted to Professor T. Akazawa of Department of Anthropology and Prehistory, the University Museum, the University of Tokyo, and Professor B. ENDO of Department of Anthropology, the University of Tokyo for approving the use of dental casts under their care. My cordial thanks are due to Professor K. HANIHARA of International Research Center for Japanese Studies for his valuable suggestions throughout this study.

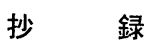

歯冠形質からみたネグリトの系統

$$
\text { 埴 原恒彦 }
$$

ネグリトはフィリピン, マレー半島, アンダマン諸 島に分布寸る採集狩猟民で低身長, 暗褐色の皮膚, 縮 毛, 等の外観的特改を示すが，その人種的起源と分化 に関しては長い間, 人類学にお汸る論争の的であっ た。最近の人類遗云学的研究によれば, ネグリトは東 南アジアを起源とする集団で，その身体的特徽は熱帯 
降雨林という環境によってもたらされた適応の結果で あるとされている (Омото, 1984: 尾本, 1986, 1987)。 本研究では, 文部省科学研究費 (海外学術調查) 「ネグリトの集団遺伝学的研究」(研究代表者, 尾本恵 市東京大学教授）によって，歯科医師酒井賢一郎博士 により収集，作製されたルソン島中西部に分布するネ グリト（アエタ）の全額石亮模型を使用，比較資料と して現代日本人, アイヌ，フィリピン人，オーストラ リア原住民，ピマーインディアン，アメリカ白人, ア メリカ黒人のデータを用いた。

歯冠計測值（第三大臼歯を除く歯冠近遠心径）に基 つく分析の結果, 眯全体の大きさに関してはネグリト は上記 7 集団中最も小さく，この点でアイヌとの類似 性が認められた。一方，Qモード相関係数に基づく形 態距離からネグリトはモンゴロイド人種のクラスター に含まれることが明かとなった。同様の結果は主成分 分析によっても示され，さらに前歯（切歯，犬歯）と 後歯（小臼歯，大印歯）の相対的な大きさに関しては ネグリトはオーストラリア原住民と同様の特徵を示す ことが明らかにされた。しかし，アメリカ白人，アメ リカ黒人との間には何ら類似性は認められなかった。

非計測的雬冠形質についてはネグリトはアイヌと共 にスンダ米型を示し， $B^{2}$ 距離 (BALAKRISHNAN and SANGHVI，1968）においても両者は強い類似性を示 した。ここでもやはり, アメリカ白人, アメリカ黒人 との類似性は認められなかった。

以上の結果は，ネグリトが人種的にアジア起源であ るという可能性を強く示唆しているものと思われる。 TURNER（1979，1983，1987，1989）は縄文人，アイ ヌが後期更新世のプロトモンゴロイドに由来し，スン タランドがその放散中心であったと考えている。一方, Омото (1984), 尾本（1986，1987）は後期更新世に スンダランドを舞台としてプロトオーストラロイドか ら進化したプロトマレーことがネグリトの直接の祖先 であるとし，さらに彼らとプロトモンゴロイドとの密 接な関係を指摘している。これらの仮説を考慮すると 今回の分析結果はネグリトとプロトモンゴロイドとの 関係についてある程度の示唆を与え得るものと思われ る。しかし, 両者の関係はさらに, 縄文時代人, 太平洋 民族等を含めた詳細な分析，検討が必要である。この 意味において本研究がその一資料となれば幸いである。

\section{References}

BRACE, C. L. and K. NAGAI, 1982: Japanese tooth size: Past and present. Am. J. Phys. Anthro- pol., $59: 399-411$.

BALAKRishnan, V. and L. D. SANGHVi, 1968 : Distance between populations on the basis of attribute data. Biometrics, $24: 859-865$.

Birdsell, B. J., 1949: The racial origin of the extinct Tasmanians. Rec. Queen Vic. Mus. II, 3: 105-122.

BiRdsell, B. J., 1977: The recalibration of a paradigm for the first peopling of greater Australia. In: Allen, J., J. Bolson and R. Jones (eds.): Sunda and Sahul: Prehistoric Studies in Southeast Asia, Melanesia and Australia. Academic Press, London, pp. 113-167.

Constandse-Westermann, T.S., 1972: Coefficients of biological distance. Humanities Press, New York, pp. 91-100.

Cadelina, R. V., 1984: Detribalization and gene pool alteration: A case of an endangered community. J. Indian Anthropol. Soc., 19: 153165.

Cipriani, I., 1966: The Andaman Islanders. Weidenfeld and Nicolson, London, pp. 77-78.

Coon, C.S., 1962: The Origin of Races. Alfred A. Knopf, New York.

Goodman, M. J., A. Estioko-Griffin, P.B. Griffin and J.S. Grove, 1985: Menarche, pregnancy, birth spacing and menopause among the Agta women foragers of Gagayan Province, Luzon, the Philippines. Ann. Hum. Biol., 12: 169-177.

GlinkA, J., 1981: Racial history of Indonesia. In: SchwidetzKy, I., (ed.): Rassengeschichte der Menschheit 8, R. Oldenbourg, München/ Wien.

HANIHARA, K., 1974: Factors controlling crown size of the deciduous dentition. J. Anthropol. Soc. Nippon, 82: 128-134.

HANihARA, K., 1976: Statistical and comparative studies of the Australian Aboriginal dentition. University Museum, University of Tokyo Bulletin, No. 11.

Hanihara, K., 1979: Dental traits in Ainu, Australian Aborigines, and New World populations. In : LAUGHLIN, W.S. and A. B. HARPER (eds.) : The First Americans : Origins, Affinities, and Adaptations. Gustav Fischer, New York/ Stuttgart, pp. 125-134.

Hanihara, T., 1989a: Comparative studies of dental characteristics in the Aogashima Islanders. J. Anthropol. Soc. Nippon, 97: 922. 
HANiHARA, T., 1989b: Comparative studies of geographically isolated populations in Japan based on dental measurements. J. Anthropol. Soc. Nippon, 97 : 95-107.

Harihara, S., N. Saito, M. Hirai, T. Gojobori, K.S. Park, S. Misawa, S.B. Ellepola, T. IsHidA and K. Омото, 1988: Mitochondrial DNA polymorphism among five Asian populations. Am. J. Hum. Genet., 43: 134-143.

Horai, S., K. Omoto, T. Juji, H. Sonozaki, H. Mitsui, S. Misawa, J.S. Sumpaico and A.S. MercAdo, 1981: The HLA antigens of two Negrito populations in Philippines. Tissue Antigens, $17: 343-348$.

Howells, W. W., 1970: Anthropometric grouping analysis of Pacific peoples. Arch. Phys. Anthropol., 5 : 192-217.

Howells, W. W., 1976: Physical variation and history in Melanesia and Australia. Am. J. Phys. Anthropol., 45: 641-650.

Howells, W. W., 1977: The sources of human variation in Melanesia and Australia. In : Allen, J., J. Golson and R. Jones (eds.) : Sunda and Sahul: Prehistoric Studies in Southeast Asia, Melanesia and Australia. Academic Press, London, pp. 169-186.

JАСОВ, T., 1967: Racial identification of the Bronze Age human dentitions from Bali, Indonesia. J. Dent. Res., 46 : 903-910.

Kennedy, K. A. R., 1979: The deep skull of Niah : An assessment of twenty years of speculation concerning its evolutionary significance. Asian Perspectives, 20: 32-50.

Kumar, N. and D.P. Mukherjee, 1983: A genetic study among the Onge of little Andaman. J. Indian Anthropol. Soc. 18: 161-168.

Matsumoto, H., T. Miyazaki, K. Оmoto, S. Misawa, S. Harada, M. Hirai, J. S. Sumpaico, P. M. Medado and H. Ogonuki, 1979: Population genetic studies of the Philippine Negrito. II. $\mathrm{Gm}$ and $\mathrm{Km}$ allotypes of three population groups. Am. J. Hum. Genet., 31: 70-76.

Oмото, K., 1972: Polymorphisms and genetic affinities of the Ainu of Hokkaido. Hum. Biol. Oceania, 1 : 278-288.

Омото, K., 1979: Carbonic anhydrase-I polymorphism in a Philippine aboriginal population. Am. J. Hum. Genet., 31: 747-750.

Омото, K., 1980: Genetic variants of red cell enzymes as potential anthropological markers in the western Pacific. Hemoglobin, 4(5 \& 6):
755-760.

Омото, K., 1981: The genetic origins of the Philippine Negritos. Current Anthropol., 22(4) : 421-422.

Oмото, K., 1984 : The Negritos: Genetic origins and microevolution. Acta Anthropogenetica, 8 (1 \& 2) : 137-147.

Омото, K., 1986: The basic population in East Asia. In: HANIHARA, K. (ed.) : The Origin of Japanese. Shogakukan, Tokyo, pp. 139-160. (In Japanese)

[尾本患市, 1986: 東アジアの基層集団. 埴原和郎 (編), 日本人の起源, 小学館, pp. 139-160.]

Омото, K., 1987: Discovery of man.-Molecular anthropology-. Yomiuri Kagaku Sensho, 14, pp. 169-204. (In Japanese)

[尾本恵市，1987：人種の 起源と交流一分子レベル で見る人種の関係一. ヒトの発見 分子で探るわれ われのルーツ, 読売科学選畵14, ライフ・サイエ ソス・シリーズ, pp. 169-204.]

Omoto, K., S. Misawa, S. Harada, J.S. SumPaico, P.M. Medado and H. Ogonuki, 1978: Population genetic studies of the Philippine Negritos. I. A pilot survey of red cell enzyme and serum protein groups. Am. J. Hum. Genet., $30: 190-201$.

Omoto, K., S. Ueda, K. Goriki, N. Takahashi, S. Misawa and I. G. Pagaran, 1981: Population genetic studies of the Philippine Negritos. III. Identification of the carbonic anhydrase-1 variant with $\mathrm{CA}_{1}$ Guam. Am. J. Hum. Genet., 33: 105-111.

REynOLDS, H., 1976: The development project of the mountain Negritos northern Negroes, Philippines. Silliman Journal: A Quarterly Devoted to Discussion and Investigation, 23(2): 182-202.

Schebesta, P., 1957: Die Negrito Asiens. St.Gabrie, Wien.

Turner, C. G. II, 1976: Dental evidence on the origins of the Ainu and Japanese. Science, 193(3) : 911-913.

Turner, C.G.II, 1979: Dental anthropological indications of agriculture among the Jomon people of central Japan. X. Peopling of the Pacific. Am. J. phys. Anthropol., $51: 619-636$.

Turner, C.G.II, 1987: Late Pleistocene and Holocene population history of east Asia based on dental variation. Am. J. Phys. Anthropol., $73:$ 305-321.

Turner, C. G.II, 1989: Teeth and prehistory in 
Asia. Scientific American, February: 70-77. Turner, C. G. II and D. R. Swindler, 1978: The dentition of New Britain west Nakanai Melanesians. VIII. Peopling of the Pacific. Am. J. Phys. Anthropol., 49: 361-372.
YamaGuchi, B., 1967: A comparative osteological study of the Ainu and Australian Aborigines. Canberra, Australian Institute of Aboriginal Studies.

\section{埴 原 恒 彦自治医科大学 第一解剖学教室 于329-04 栃木県河内郡南河内町}

Tsunehiko Hanihara Department of Anatomy, Jichi Medical School Minamikawachi-cho, Kawachi-gun, Tochigi-ken 329-04, Japan 